\title{
Hermeneutics and Its Discontents in Philosophy of Science: On Bruno Latour, the "Science Wars", Mockery, and Immortal Models
}

Babette Babich

Fordham University, babich@fordham.edu

Follow this and additional works at: https://fordham.bepress.com/phil_babich

Part of the Environmental Studies Commons, Philosophy of Science Commons, Political Theory $\underline{\text { Commons, }}$ and the Social and Cultural Anthropology Commons

\section{Recommended Citation}

Babich, Babette, "Hermeneutics and Its Discontents in Philosophy of Science: On Bruno Latour, the "Science Wars", Mockery, and Immortal Models" (2017). Articles and Chapters in Academic Book Collections. 81.

https://fordham.bepress.com/phil_babich/81 
Babette Babich

Hermeneutics and Its Discontents in Philosophy of Science: On Bruno Latour, the "Science Wars", Mockery, and Immortal Models

\begin{abstract}
Themes discussed include a hermeneutic of hermeneutic philosophy of science, along with the hegemony of analytic style in university philosophy in the US and Europe as well as the rhetoric of power, highlighting the politics of mockery using the example of Alan Sokal's hoax as this sought to exclude other voices in the academy, especially philosophy of science. In addition to reviewing Sokal's attack on Bruno Latour, Latour's own "biography" of an investigation is read as articulating a doubled hermeneutic reflection on modernity including both field ethnography and lab-ethnography. The further question of the viability of a hermeneutics of science in general, both natural and social is raised, thematising Patrick Heelan's "readable technologies" as metaphor for scientific research practice. Including a discussion of peer review and the editorial vicissitudes of journal publication, this chapter also addresses the politics of scientific models using the metaphor of immortality, zombie-style.
\end{abstract}

\title{
I Science Wars
}

The so-called science wars would seem to have been thoroughly fought and utterly decided on the side of the angels. ${ }^{1}$ It seems, in today's era of post truth, we need science and reason more than ever. We might even be said to need a present-day Galileo to stand up to some of the attacks on science from so many sides. But hermeneutically considered, historically considered, as Paul Feyerabend reminds us in his essays on Science for a Free Society, things were not cut and dried when it came to the original Galileo, the "pushy patron saint of science." More than pushy, as Feyerabend liked to repeat in conversation with the author, Galileo was "a crook." Feyerabend's colorful and hyperbolic description is not far from the truth and, by any standard, Galileo was an opportunist: capable of giving his word (to Cardinal Bellarmine) and capable of breaking it. Speaking of the

1 Stengers 1977.

https://doi.org/10.1515/9783110528374-009 
contest between rational discourse schemata or models, ${ }^{2}$ or more methodologically, in Against Method, Feyerabend points out that Galileo offers "arguments in appearance only," making the case he makes for science via rhetoric or more bluntly still, via "propaganda." Thus Galileo did what all science does, ${ }^{3}$ using "psychological tricks in addition to whatever reasons he has to offer." ${ }^{4}$ Feyerabend's judgment contravenes a received prejudice concerning the objective manner in which we suppose that modern science came to be modern science.

To his credit as a historian of science, Feyerabend's account follows the historical record more closely than the image of Galileo as martyr ${ }^{5}$ persecuted by the church. Bertolt Brecht's Galileo is, by contrast, a modern morality tale like Jean Anouilh's Antigone and in many other philosophical accounts, it can seem that Galileo is revered as a saint of truth in the face of the Harry Potteresque "dark" arts of the church. ${ }^{6}$ Science is the hero, as we know but, just to the extent that today's church no longer has the power to play the role allotted to it, science (or its public voice) is compelled to cast about for a suitably dark alternative enemy and it has found it in the various names of relativism and constructivism and not less as in the case of Sokal's original 'fake news,' structuralism, deconstruction, and postmodernism, alt- and post-truth.

As arbiters and defenders of science, what is important is that we modern intellectuals declare ourselves opposed to the side being mocked or 'parodied' and thereby ally ourselves with the winning side, the side of the enlightenment. But as, at least one mainstream scholar, P.M.S. Hacker has observed, there

are far too many philosophers who take their task to be to sing the Hallelujah Chorus to the sciences. It seems to me we should be serious, and one hopes helpful, conceptual critics of the sciences. (Hacker 2010)

2 Feyerabend 1985, here on models, p. 158. On the claim that Bellarmine was more respectful of alternate viewpoints, i.e., less dogmatic, than Galileo, see p. 166.

3 See among his other studies, Latour 1976 as well as Latour and Woolgar 1986 [1979], among, recently, not nearly as many others as there might be.

4 Feyerabend 1993 [1975]). Of course, it is not for nothing that John Horgan was moved to title, only somewhat tongue in cheek his "Profile: Paul Karl Feyerabend-The Worst Enemy of Science” (Horgan 1993). See further, Preston, Munévar and Lamb 2000.

5 On Galileo, Alan Chalmers is most comprehensive but there are others, such as more sustainedly, Finocchiaro 2010. And in the history of science, see Nicholas Jolley or indeed the general shift in the field over the last twenty years. And see too Heelan 1994.

6 I am making the points as Feyerabend has highlighted them both in his published work and in conversation with me, but the point is highly complex and involves rhetoric all the way down. See for a slightly different reading, drawing on Stengers, Pelchat 2003. 
Hacker's recommendation, modest as it is, to be "serious, and ... helpful, conceptual critics of the sciences," is a minority voice among philosophers and public intellectuals of all disciplinary stripes. For, in the wake of the science wars, the science side counts as the winning side and it is in accord with this that Alan Sokal had originally articulated his so-called "hoax." Significantly, Sokal's hoax elicited no debate apart from uniformly scandalized response: for no one came out opposed to Sokal's position. ${ }^{7}$ Indeed, the entire hoax took place on just one side, with Sokal himself playing both sides in a dispute he authorized (and this, among other things, is the reason it was not, despite his insistence that it was, a "parody"). No one took the side of postmodern science in the so-called science wars, and to this day, few scholars have undertaken to defend hermeneutics, ${ }^{8}$ not even Bruno Latour.

Thus when Sokal, a physicist, in an interview in Le Nouvel Observateur, raises the question in the light of media attention that was the aftermath of his hoax, "Are our philosophers imposters?", 9 it is important to emphasize that Sokal takes the term "philosopher" very broadly, including as he does whole other disciplinary fields, including Donna Haraway's biology (and her feminist history of consciousness) and Stanley Aronowitz's sociology together with Luce Irigaray's linguistics and psychology (count in Lacan as well), all along with the same Derrida

7 Typically, discussions of Sokal's hoax attack the humanities and the supposed failure of peer review. And the discipline of science studies, especially in history and sociology, which had had some critical elements quickly jettisoned those components in the wake of the media success of the hoax. Without exception, discussion of Sokal's work lionized his achievements. See most recently Corneliussen 2017 and Ruark 2017.

8 My own essay on Sokal was an exception and it remains one of the only critical responses to Sokal. Indeed, it is rarely, if ever, cited and from the start it was astoundingly difficult get into print: I sent it everywhere, even writing to Tracy Strong, who had originally emailed me about Sokal's hoax (at the time he was editor of Political Theory), to ask that he consider it. No luck. Finally, a bowdlerized version (courtesy of Paul Piccone's Telos) was published under a title that was not mine: "Physics vs. Social Text: The Anatomy of a Hoax" (Babich 1996). A year later it was published in Common Knowledge, thanks to the graciousness of an editor, Jeffrey Perl (who organized a special section around my essay, including an essay by Feyerabend and another by Barry Allen), with its original title: "The Hermeneutics of a Hoax" (Babich 1997). If articles are turned down all the time, for all kinds of reasons, this article happened to have been presented at a conference on Hermeneutics and the History of Science, at Stony Brook in June of 1996, which yielded not one but two sets of conference proceedings, the point of which "proceedings" being to ensure the dissemination of the papers presented: firstly in an issue of Man and World, edited by Robert Scharff, who excluded my contribution, which was also then excluded from the volume edited by Robert Crease. The political aspect of editorial gatekeeping is taken up in the context of coastal engineering in the fifth section below.

9 [Nos philosophes sont-ils des imposteurs ?] Sokal 1997b. 
analytic philosophers were then anxious to denounce (not a lot has changed). Thus even after his fake news text and its decoder-ring bookend (didn't mean it, how could you not know?), Sokal mocked "The Philosophical Mystifications of Professor Latour."10 But would Social Text (or Le Monde) have published the latter without the 'hoax' orchestrated between two publications, with the blessing of two sets of editors, one set supposed to have been hoodwinked, Social Text, the other, unveiled as the editorial locus of truth, Lingua Franca, (at the time, the academic equivalent of Fox News)? The achievement was a staged or "post-truth" event.

It is the mockery that matters now, because it is this that Sokal was permitted to publish about Latour, a fair amount of it elliptical, including this damning paragraph:

I will not detail for the readers of Le Monde, explicating the "scientific formation" manifested by Latour in his essay on the Einsteinian theory of relativity, that which was presented as a "contribution to the sociology of the delegation" (Social Studies of Science 18, pages 3-44, 1988). These details appear in the book Jean Bricmont and myself are currently in the process of writing on The scientific impostures of (post) modern philosophers. Suffice it to say that certain colleagues suspect that Latour's article was, just as mine was, a parody. (Sokal 1997a)

Sokal continues to play the science card, natural scientist contra social scientist, distinguishing inexact from exact sciences, a rank-ordering move, i.e., my science is more scientific than yours:

Latour accordingly pretends to address the sociology of science but his expose is confused: he mixes up ontology and epistemology and attacks claims that no one holds. "In place of recognizing a science holding absolute exactitude in its knowledge, one recognizes in its place the quality of the collective experience it demonstrates"-yet who today claims that science furnishes 'absolute exactitudes.' (Sokal 1997a)

10 Sokal 1997a. This did not go away quietly, to be sure. See Joerg Lau (2002), The argument here in 2002 against "political ecology" and against indeed the ecology of things, of nonhuman objects, has in the interim gone over in the field of political theory and philosophy not to mention media ecology to Latour's side, at least and arguably more rather than not. Lau's essay was written as a review of the German translation of Latour's Politiques de la nature. Comment faire entrer les sciences en démocratie (Latour 1999) (already cited in English and cf., too, Latour, Das Parlament der Dinge (Latour 2001) but see Latour 1991a, where he speaks of the idea of a 'democracy extended to things', a project since executed with some panache. See also for one approach to this question, Schmidgen 2014, pp. $108 \mathrm{ff}$. 
At issue is expert power and public voice: at issue, who should be permitted to speak and who should be silenced.

Thus Sokal's ambition, which was largely if obviously in the case of Latour not completely successful (which does not mean that it was without effect for Latour himself), was to silence these and related voices, using the tactic of discrediting, after which the idea was to have these names and all their writings fall from mention: as if they had never been on the horizon of scientiifc exchange. To this day, non-mention is the way scientific authority continues to work: it determines who gets funding and is the engine of nothing less than the vetting and thus the literal "genesis and development" of today's scientific facts. ${ }^{11}$

Where philosophy traditionally serves as handmaiden or servant-the old word is "ancilla" - to theology, sine qua non as it is for theological reflection, the new modus of philosophy has ambitions to serve science, telling science what it can and cannot do. There are troubles with this ambition and the physicists have been reluctant to welcome the philosophers as either methodological instructors or logic coaches. Thus Stephen Hawking declared, some years ago attracting media attention-and never himself bothering to retract the claim-“Philosophy is dead." (Warman 2011)

\section{Les “Pseudos”: Science vs. Pseudoscience}

Given the economic constraints of the current day in the academy, the growing trend in almost all disciplines is that of suppression by threat: say what everyone else says or (and this is a real threat) you won't be hired, you won't be tenured, you won't be published, or if you are, you won't be read. To this extent, the ongoing non-citation of outlier views is deliberate and yields nothing less than what Thomas Kuhn called "normal science." Thus Latour offered his own recent reflections on the "disciplining" of anthropology, ${ }^{12}$ departing from just that very hermeneutic philosophic sociology of ethnographic science of both field ethnography and lab ethnography as Latour practiced both of these kinds, relating the history, the bio-graphy of this practice. It is important to underline that this aca-

11 I have elsewhere written about what is done when academic authors dismiss the work of a university scientist by belittling him as a "pseudoscientist." See Babich 2015. The tactic is rhetorical one: a matter of disciplining, and it makes and breaks careers and, indeed (both during a lifetime and posthumously), reputations.

12 Latour 2013. 
demic story of a lifetime, ${ }^{13}$ that is, just as Latour underscores, not a matter of $a u$ tobiography, was offered as it was across several books, and several platforms, including workshop collectives and the internet as well as online publications and books, thus entailing that Latour's own reflections are to be ranged under what Anthony Giddens and, in this current volume, both Dimitri Ginev and Simon Glynn call a double hermeneutics. ${ }^{14}$ Latour thematizes just this double hermeneutic: the ethnographer is barred from observing the practice of the "whites," reflexively redoubling the ethnographer's own doubled hermeneutics. Here, broadly speaking, we might say that the "whites" refer to the natural sciences entailing that anthropology and other social sciences are excluded from the greater philosophic conversation on science. Indeed, it is only recently, after severe criticisms in part related to anxiety about constructivism and in part related to the Sokal hoax, and consequent retrenchments that for decades limited the purview of Science Technology Studies, seemingly gutting the socalled Strong Program in the process, that some ginger efforts have been made to return to Latour's lab ethnography. ${ }^{15}$

Taking his own point of departure from a reflection on Etienne Souriau's "different" scientific "modes d'existence,"16 Latour invited 'open"17 exchange on the movement in philosophy known as the "speculative turn." 18 The Souriau

13 Reflectively different in kind, for example, from either Martin Gardner's (2013) confidently pseudo-bashing autobiography or Paul Rabinow's (2011) Foucault-themed reflections or Geertz's (1996) own auto-reflections.

14 See Ginev 1998 as well as for contextualization with reference to Luhmann, Leydesdorff (2006) and Lynch 1993. Note that Mike Gane offers an illustration of Comte's double hermeneutics, which Gane analyses as a "two-fold hermeneutic" in the context of a discussion of Latour and Comte. Gane 2006, pp. 95-97. And see too, on Latour, with respect to Alfred Schutz, Bischur (2013). And see too more generally, the contributions to Maranhāo and Streck (2003).

15 See Sormani (2016).

16 Souriau 2009.

17 Of course it was not really 'open.' See note below.

18 The speculative turn also goes by the name of 000 (and there are other names). It is true to say that Latour engaged this movement quite in his own fashion (this has ever been his wont) going beyond what some analytic (and some self-describedly so) "continental" scholars might call "experimental philosophy" towards what mattered for Latour and his studies of laboratory science including his turn to political ontology and thus to things environmentally, empirically encountered as we find them as they act. As Latour explained (and although he meant this literally it would turn out to have disputed significance for those scholars who took his internetdisseminated call seriously): "I invite my co-investigators to help me find the guiding thread of the experience by becoming attentive to several regimes of truth, which I call modes of existence, after the strange book by Etienne Souriau, recently republished, that features this phrase in its title" Latour 2012, here p. 1. 
text to which Latour, along with his co-editor Isabelle Stengers, referred was initially published in 1943, ${ }^{19}$ permitting in this context Latour to explain his approach to anthropology of science not as ethnography and not as social studies of science and technology but as philosophy of science as such. I note that some saw this invitation as a venture to bring disparate voices to dialogue in the philosophical academy. ${ }^{20}$ But what was at stake was more than a matter of diversification but all about the exclusion that was already and from the start an exclusion of Latour's own voice.

Thus one might read Latour's We Have Never Been Modern ${ }^{21}$ as a contribution to what might be counted as a national or "territorial" geography of science, not just European and non-European, not just French and southern Californian (San Diegan), but into the interstices of the academy of analyses tolerated and analyses barred. Inevitably this is a matter of translation and cultural formation. Thus what Latour offers is one of the first of its kind since Pierre Duhem's almost unread German Science ${ }^{22}$ or Paul Forman's (1971) argument that a conceptual culture of philosophy would be indispensable (and for all kinds of reasons ultimately to be lacking) for understanding, in the title of one his articles on his thesis, "Weimar Culture, Causality, and Quantum Theory." Forman's thesis was both completely received (or successful) and misunderstood, a matter of inevitable dispute to this day inasmuch as the 'culture' of philosophy Forman was pointing to was nothing less than continental philosophy, the kind of philosophy foregrounding hermeneutics and phenomenology etc., the very philosophy advanced by the philosopher and physicist, Patrick Aidan Heelan (1965, 1994, 2016, etc.) It matters to observe that the contributors to Carson et al. (2011) although celebrating Forman as they were, did not, rather of necessity, have a formation in this particular culture of philosophy (and which might have aided them in unpacking Forman's arguments) owing to the dominion of analytic approaches in professional Anglophone philosophy over the last several decadesa rise to power that began, according to Reiner Schürmann $(1985,1994)$ already

19 Souriau 2009.

20 This it was not to do and when the project had run its course the players were the same names in the Latour camp (and in the camp of speculative philosophy) that had been involved at the start. No others. To be sure, here and there there were little virtual fisticuffs on Twitter, but little to write home about and nothing Latour would have noticed in any case. I discuss this more socio-political dimension in a longer version of this essay (Babich 2017), and see in particular (in French), Babich 2018.

21 Latour 1991b. It matters that Latour writes an afterword to the French translation of Fleck 2008.

22 Duhem 1991 [1916]. 
in the US as early as the 1960s, and which was certainly well established as an almost hegemony as the current author can attest by the 1970s. Several things obscure this claim, not the least of which is the habit of analytically formed scholars to regard themselves (and insist on being named by others) as continental if the themes (or names) they study are continental..$^{23}$ But there are additional difficulties to reading the Forman thesis because historical discussions of the rise of analytic hegemony in university philosophy are politically clouded (Weimar culture is perhaps all the cloud one needs but McCumber and others add McCarthyism in the US). ${ }^{24}$ Here what is essential is the conceptual criticism Hacker had emphasized as quoted above and Forman's thesis remains salient just where what is at stake is both high philosophy and high physics. Nevertheless, ${ }^{25}$ students of history and philosophy of science do not as a rule learn the actual history of contemporary academic philosophy but only what analytic philosophers call the history of philosophy, not even when what is at stake concerns, as Forman's thesis concerned the time span 1918-1927, an interval including the publication of Heidegger's Being and Time.

For his own part, Latour's concern is not Forman's and neither hermeneutics nor phenomenology are thematic for Latour, although he draws on the resources of both approaches. Significant, with respect to ethnography and double hermeneutics, is Latour's reflection on reflection: we investigators, philosophers, thinkers, researchers, ethnographers, we "whites," perpetually manage to fail to put ourselves as investigators in question.

To "the classical question of philosophy 'what is the being of technology, science, religion?" is added the question favored by so-called object-oriented ontology, which Latour rearticulates, thereby "pluralizing" the question: "what are the beings appropriate to technology, science, religion, and how have the Moderns tried to approach them?"26 And of course favoring the focus on things, this could be similarly varied. In his own reflection, Latour invokes his teacher at Dijon, André Malet, to reflect that the "science" of reading, including classical and theological philology presupposes a specific anthropology of reception. As is by now familiar, we note the absence of the word hermeneutics when speaking of hermeneutics:

23 Thus Gary Gutting gets to count as continental having written on Foucault which would make Ian Hacking continental too, and why not, as I understand: he lives in France? It also makes the late analytic Heideggerian Bert Dreyfus 'continental' and of course Brian Leiter is continental as well.

24 See McCumber 1996 and see further Glendinning 2006 and Cutrofello 2004.

25 See Shapin 1992 and Kusch 2005.

26 Latour 2012, here p. 2. 
the Biblical text finally became comprehensible, revealed as a lengthy process of transformations, inventions, glosses, and diverse rationalizations which, taken together, sketched out a layer of interpretations that played out-this is the essential point-each in its own way the question of fidelity or treason: faithful or falsified invention, impious reworking or astounding rediscovery ${ }^{27}$

If Clifford Geertz almost patented the practice of talking hermeneutics without saying the word-lock, stock, and cockfight barrel ${ }^{28}$-Latour is also telling his readers and himself, his own biography (bien entendu, under negation: "Not to tell my life story-if a system is solid, one need not be overly concerned with its author-but rather to sketch the biography"). ${ }^{29}$ The apology here is my own but in his own voice Latour tells us that he knows of "no other author who has so stubbornly pursued the same research project for twenty-five years, day after day, while filling up the same files in response to the same sets of questions," also informing us of the challenges he faced, together with "a wife and child," in order to make the discovery in "the Abidjan of 1973-75 ... all at once the most predatory forms of capitalism, the methods of ethnography, and the puzzles of anthropology." 30 The effects of this insight are articulated further in his more recent book ${ }^{31}$ to the height of persuasion, revealing the obstacles encountered along the way as sources of both affirmation and desolation.

For Latour,

one puzzling question in particular that has never left me: why do we use the ideas of modernity, the modernizing frontier, the contrast between modern and premodern, before we even apply to those who call themselves civilizers the same methods of investigation that we apply to the "others"-those whom we claim, if not to civilize entirely, then at least to modernize a little? ? $^{32}$

I am not able to develop this point as I seek to address it elsewhere but it applies to the distinction to be drawn between science and pseudoscience as well as to the status to be claimed in order to be named a philosopher of science like Ludwik Fleck (not to mention Heidegger or Nietzsche). Thus Latour can continue to reflect on what he names a "flagrant asymmetry," which we may also regard as

27 Latour 2012, p. 3.

28 But see for a discussion, largely via Ricoeur, of Geertz on space and place, Aucoin 2017. And for further discussion of anthropology and hermeneutics, see Kämpf 2013 and see too in the same collection, Dallmayr 2013.

29 Latour 2012, p. 4.

30 Latour 2012, p. 4.

31 Latour 2013.

32 Latour 2012, p. 4. 
the default of hermeneutics, simple and above all doubled or reflexive, observing as the key question perhaps of social science as a science that

... the Whites anthropologized the Blacks, yes, quite well, but they avoided anthropologizing themselves. Or else they did so in a falsely distant, "exotic" fashion, by focusing on the most archaic aspects of their own society-communal festivals, belief in astrology, first communion meals-and not on what I was seeing with my own eyes (eyes educated, it is true, by a collective reading of L'Anti-Oedipe): industrial technologies, economization, "development," scientific reasoning, and so on: in other words, everything that makes up the structural heart of the expanding empires. ${ }^{33}$

Latour's path in search of symmetry (and asymmetry) may be illuminated by the cover of Latour and Woolgar's Laboratory Life (1986 [1979]), not the words themselves of that fatal subtitle The Construction of Scientific Facts (I write about this elsewhere $)^{34}$ but a legend on a book cover: "Introduction by Jonas Salk." To this extent, Latour's transgression-it was not a "violation," of scientific objectivity as much as it was a documention of the process-took him to his on-going success (or influence) in the guise of his own study of neuropeptides qua actors qua actants, and that "violation" was his attention to the scientists themselves in the laboratory itself.

Latour's own success (if this is what matters) crystalized when his attention shifted to the things themselves, the objects as such, the "nonhuman characters." Thereby, and just this is an achievement for objectivity, one excluded the human from the human sciences, excluding the agency of human agents along with human social practice. For Latour:

I suddenly understood that the non-human characters had their own adventures that we could track, so long as we abandoned the illusion that they were ontologically different from the human characters. The only thing that counted was their agency, their power to act and the diverse figurations they were given. ${ }^{35}$

This question of investigation and influence returns, as every reader of Latour's reflections will go on to discover for themselves and to rediscover, if they care to do this, for the rest of their lives. Here it is enough to presage the point in terms

33 Latour 2012, p. 5.

34 Note the scare word "construction" as this would perturb both Ian Hacking and not less Bruno Latour himself as critics (not only the likes of Alan Sokal) turned the term against them by using it to characterize their own work-this sensitivity engendered no fewer than two books one by Hacking and another, earlier at the same press by Latour.

35 Latour 2012, pp. 6-7. 
of Latour's own rueful musing on what response he might have had had one ever indeed thought to ask him about his own "philosophy" (Latour brackets this reflection, writing parenthetically):

(Not to worry: no one has ever asked me that question, since the tumultuous quarrels over relativism and the science wars have in the meantime turned me into a mere sociologist, adherent of a "social construction" according to which "everything is equal," objective science and magic, superstition and flying saucers ..... ${ }^{36}$

Rules and the roles of demarcation remain and in Latour's little list of relativized damnations, Feyerabend's famous damnation, astrology, no longer rates a mention. And to this day in the academy one cannot or, better: may not-not if one wishes to have one's projects find funding, not if one wishes a university appointment-say anything but what the received view allows.

At stake are issues that should concern us whatever our formation in our deepest prejudices as academics, members of the university profession and that is the life of the mind, to use Hannah Arendt's formulation for what Arendt conveyed as politically as she did. Thus, to note a sociolinguistic hermeneutic assumption, we remain convinced that if only our discourse were clear enough, if only our style were rightly framed, with just the right words, the right punctuation, we might, have success in our grasp. This conviction preserves the power of those in power. We thereby pretend style has no play (we suppose anything can be said 'clearly') and influential scholars declare there is no distinction between analytic and continental philosophy (this is what has been learned by most younger scholars and it has truth inasmuch as the only philosophical kind left standing is analytic), and that the only thing that decides a grant application, publication success, a university post is quality, a conviction enthusiastically repeated by those with grants, regular publications, job security, etc.

In a 'post-truth' era, in these days of so-called 'fake news,' it is sobering to note one consequential reflection on the fallout from Sokal's hoax, quite apart from the violence and fading relevance of his attacks on Bruno Latour and others. Because, as we may be learning, the method of using mockery or what Sokal calls parody to attack a scholarly colleague whose claims one does not like, like witch-hunting in the past, can cover any number of sins without needing to make a logical case at all. As the historian Ellen Schrecker observes: "Today is the culmination of 40 years of attacks on academic expertise. It's fine if you

36 Latour 2012, p. 13. In a recent reading from the side of the humanities of Serres and Latour, the word hermeneutics appears once as a reference to Ricoeur. See Connor 2016. 
want to make fun of deconstruction, but it's not fine if you make fun of climate change." 37

Faults one may wish to lay to the account of so-called 'deconstructionists' and 'postmodernists' can come to haunt more respectable scientists in an era of generic denial of expertise, extending as Schrecker emphasizes, to the science authority we wish to claim on climate change and so on. Thus science itself polices its more speculative voices, especially on controversial topics including vaccines and homeopathy (we already have the truth) ${ }^{38}$ or the industry assertion that cell phone radiation is just fine (does everyone not have a cell phone? Is not WiFI or WLAN omnipresent?), or the political assurances that fracking is perfectly good for the environment, dams grand for the Amazon, and GMOs likewise fine and so on and so on.

Indeed, it can be hard not to wonder if the language of 'post-truth' itself is not a bullying tactic, just as Sokal's hoax was a bullying tactic, deployed in his case from the side of hard science, against the softer, social kind, and in our era of political concern, deployed by a regime nostalgic for a single media voice and anxious to silence different voices.

\section{Beyond the 'Good' and the 'Bad'}

Recall Nietzsche's (in context stridently misogynist, as Nietzsche's theme here is feminine fashion allure) reflection in Beyond Good and Evil:

It is "the slave" in the vain man's blood, a remnant of the craftiness of the slave ... which seeks to seduce him to good opinions about himself; it is likewise the slave who immediately afterwards falls down before these opinions as if he himself had not called them forth. (BGE 261)

If such seductive persuasions correspond to slavish atavism as Nietzsche says, what else drives our responses to books, to looks, to Facebook and Twitter but also to our colleagues and our university research interests? Where in the face of all these "prejudices" as Nietzsche speaks of them, as he argues that such prejudices characterize not only philosophy but also science and even logic and mathematics, where shall we find the old enlightenment ideals of objectivity, science, truth? Or is this just part of the problem?

37 Cited in Ruark 2017 and Corneliusson 2017, among others.

38 See further Babich 2015. 
Overall, the philosophical question of good and bad includes the challenge of knowing which is which. Familiar to us since Plato, how can we tell friends from enemies? Thus we may recall the popular cultural case of Alan Rickman's Severus Snape as he played the character of this originally reviled, qua overly severe, teacher ${ }^{39}$ ultimately shown however to have been a hero (by which is meant that he was on Harry Potter's side in the Harry Potter series): supposed enemies can turn out to be really good despite appearing to have been really bad. Yet what if those we think bad are not villains but "interesting people" (as Rickman himself once put it)? Why is goodness assumed to be recognizable and why is it assumed that what is good would be something that would favor us (or Harry Potter)? Are we sure we would know the good if we encountered it, or that our taste would suffice as a test? For Nietzsche, there is a circle here and he elsewhere writes, in some seriousness I believe, that it is a great pity that nature does not single out excellent human beings with a kind of glow or beam of light such that one might know them with certainty rather than guess and deduce and be misled and disappointed as Nietzsche himself was and to his pain.

What are we to do about bad science or about scholars we regard as lacking? The academy is an institution formed to make such judgments: we do not want poor or bad scholars and we assume that a person who holds an appointment has a certain level of achieved excellence although this did not halt Sokal in his efforts to attack Latour, Derrida, et al and it does not stop us when we reject proposals for inadequacy. I am speaking of the assessments made by peers, who have-as this is the point of being a peer-a very personal stake in the same game.

In part, but only in part, this complex inter-involvement is one of the reasons, writing in the Journal of the Royal Society of Medicines, Richard Smith offers when he assesses peer review as a "flawed process." 40 Smith is not the only one to make this kind of observation, minimally as he makes it. But, as one congressman observes in a congressional review of the NSF in testimony given forty years earlier than Smith's essay, peer review is patently

an incestuous buddy system that frequently stifles new ideas and scientific breakthroughs, while carving up the multi-million dollar federal research and education pie in a monopoly game of grantsmanship..$^{41}$

39 See for a discussion of Snape as teacher, Babich 2016b.

40 Smith 2006.

41 Arizona Congressman John Conlan to a July 1975 hearing on the NSF peer review system. Cited in Cole, Rubin, and Cole, (1978), p. 11. 
In the case of science (this was the heart of the Sokal hoax), peer review can cover over fraud, bogus results, plagiarism, or, in the case of Sokal himself who passed peer review, after all, fakery. And in the case of both scientific and humanities scholarship what is at stake are assessments of quality.

\section{Philosophical Canons, Reading Texts, Reading Technologies}

In the case of both the natural and the social sciences, there can be no greater pitfall than the conviction that hermeneutics is limited to texts and text practices. Much rather the "text" in each case when it comes to hermeneutics concerns the matter, i.e., the 'things,' as Heidegger transformed Husserl's phenomenology, themselves. In science, such 'things' correspond in each case to a disciplinary transform. But when György Márkus wrote a petitio principii into his title, which he doubtless did for rhetorical effect: "Why Is There No Hermeneutics of Natural Sciences," ${ }^{42}$ Markus himself never read the positions his title wrote out of existence from the start quite in spite of his thematic focus on reading.

Begging the question, Markus automatically, this is the way presumption works, overlooked Patrick Heelan's arguments (in book and article form) for a hermeneutic philosophy of physics, specifically advanced with reference to quantum mechanics. Nor did Markus read Joseph J. Kockelmans nor Ted Kisiel, just to name some Anglophone names (of course there are German and other names, and, of course, there are Hungarian and Bulgarian and Italian other names) of the leading proponents of the very same possibility of the hermeneutics of natural science Markus sought to rule out of court, a tactic not dissimilar to Sokal's practice. Heelan, however read Markus with characteristic generosity and responded to his points in scholarly if gently didactic fashion: "There is a Hermeneutic Philosophy of Natural Science." 43 And that might have been the beginning of a discussion but it was not and Markus knew no more of Heelan's argument after Heelan replied to him than he had known to begin with.

42 Markus 1987.

43 Heelan 1989. See also, addressing Markus, Ginev 2006, pp. 63-65. Regrettably although Paul Rabinow 2011 foregrounds Markus and his "haunting' challenge, Rabinow claims, writing a decade and a half after Markus' original publication that no one had responded to Markus' challenge: Rabinow 2011, p. 178. To make this claim Rabinow had to overlook Heelan's reply in the very journal where Marcus's essay had first appeared. To aid Markus himself, Heelan's essay was also translated into Hungarian in 2001. 
Circularity-circular arguments included-has closure as a virtue and it seems that one can one win academic one upmanship by the expedient of ignoring a critic or a respondent rather than by taking the time to reply to them and to engage in a conversation that may show you not only the limits of their case but and always potentially your own.

To mistakenly limit hermeneutics to a textual practice (as Markus does), i.e., to the "interpretive encounter of a reader with a text" ${ }^{\text {"4 }}$ misses the metaphor of the text as experimental setup or instrumental context articulated in and through Heelan's language of 'readable technologies.' As Heelan argues, the scientific experimentalist ${ }^{45}$ is not "reading" his instruments as one reads a text but rather as one might "read"-metaphorically speaking-a painting, a landscape, a face, a gesture, or, or selecting points of significance in a data set, or, in the case of the social sciences, a community practice. To be sure, Heelan's insight may be connected, as he himself connects it, not only with Heidegger but also with Michael Polanyi and Norwood Russell Hanson as much as with Ludwik Fleck, who engaged both sociology and ethnography in his own classic discussion of the genesis of a scientific fact.

\section{Models: Data-Vicissitudes and Textbook Timelessness}

The above hermeneutic points may be illuminated with a final example on real politics in the science of climate change in connection with environmental science and the 'politics' of scientific modelling. In his book, Useless Arithmetic: Why Environmental Scientists Can't Predict the Future, co-authored with his daughter, Linda Pilkey-Jarvis, the coastal scientist, Orrin H. Pilkey discusses the politics of journal practices, including peer review practices, as these directly shape a science as such, defining knowledge regimes in the process. Thus the Pilkeys relate some of the challenges involved in the unresolved (and unresolvable), problem of shoreline erosion, locus of today's highly politicized debate regarding climate change, reflecting "the negative global impact of the greenhouse effect." ${ }^{46}$ The pattern the Pilkeys trace has less to do with shoreline erosion (although their theme is shoreline erosion) than the difficulty of addressing not a science-illiterate public but research publication with respect to journal (and

44 Nordmann 2008.

45 Of special value here is Rheinberger 1997.

46 Pilkey/Pilkey-Jarvis 2007, p. 92. 
by extension: textbook) editors concerning nothing so crucial as a model and the very theoretical idea of modeling as such.

Pilkey explains that

Criticism of quantitative beach modeling is either avoided or suppressed by applied beach modelers. Instead of debating the issue in order to recognize the limitation of models, consultants and the Corps of Engineers erect a stone wall between the modelers and their critics. ${ }^{47}$

To be sure, Pilkey assumes that debate on models flourishes in the (ideal) research sciences even as he knows it to be suppressed in (in fact) his own field:

Research scientists thrive in an environment of criticism and analysis, but in the technical coastal modeling literature, criticisms are nearly non-existent and the models remain unchallenged. To criticize is an almost ungentlemanly thing to do..$^{48}$

For Pilkey, the modelers (and in this case, the engineers) knowingly apply a bad model, justifying the practice by saying that "it is all that they have at this time." 49 The problem for Pilkey concerns the limitations of the model which is presented as if it might someday be improved. Instead, Pilkey emphasizes that when it comes to coastal models: "nothing better is coming along. They can never be quantitatively modeled with sufficient accuracy for engineering purposes."50 The result is a proliferation of zombie, i.e., 'immortal' models.

At issue is not merely complexity (beaches cannot be quantitatively modeled) but empirical practice, the standard account of comparing predictions with results, Pilkey writes:

Long term monitoring is almost non-existent, and meaningful objective comparisons of model predictions and the results is virtually non-existent. ${ }^{51}$

The problem of zombie models in science is complex and the Pilkey's epigraph from The Sea of Cortez by John Steinbeck and Ed Rickets is on point:

47 Pilkey/Pilkey-Jarvis 2007, p. 136.

48 Ibid.

49 Ibid.

50 Pilkey /Pilkey-Jarvis 2007, p. 137.

51 Pilkey/Pilkey-Jarvis 2007, p. 137. The "refrain" in question, as Orrin refers to it, was uttered by Robert Dean and James Houston, then Head of the U.S. Army Corps of Engineering Coastal Engineering Research Center in a review responding to Pilkey/Dixon 1996. 
There is one great difficulty with a good hypothesis. When it is completed and rounded, the corners smoothed, the content cohesive and coherent; it is likely to become a thing in itself, a work of art ... One hates to disturb it. Even if subsequent information should shoot a hole in it, one hates to tear it down because it was once beautiful and whole. ${ }^{52}$

Such a "perfect" hypothesis is the Brunn Rule, "the single most widely used mathematical model to predict the outcome of a natural process on the surface of the earth. Its heuristic appeal and simplicity are apparently irresistible." ${ }^{53} \mathrm{Ar}$ guing that the having of the model means that the coastal engineer goes on proposing engineering solutions-year after year-in the face of failure and despite negative feedback - the authors call for an alternative to this routine dependence on "bad models" emphasizing that only such bad models are available. That is why they are immortal.

This can be hard to understand for both the public and the bureaucrats who use such engineer's models oblivious to the "limitations of modelled predictions." ${ }^{54}$ And yet, on Pilkey's account, to raise questions contra a standard model is sufficient reason for editors to bar an author from publication. ${ }^{55}$

There are two issues at stake: one is the patently socio-political issue of challenging a received view (this is not done) and the other has to do with the seeming deathlessness, or zombie 'immortality' of models in science:

Clearly, the mathematical modelling community believed so strongly in models that it insisted on using them even when there was no scientific basis for their application. The discredited Brunn Rule predicts how much shoreline erosion will be created by sea-level rise and since no other model claims to do this, the Brunn Rule remains in widespread use. [Similarly] The maximum sustainable yield is a concept that fishery models are still using as a means to preserve fish population despite the fact that the concept was discredited thirty years ago. ${ }^{56}$

Given quantitative pressures in today's social science, rational choice (even including a direct parallel with hermeneutics in economics), ${ }^{57}$ the standard culture

52 Pilkey/Pilkey-Jarvis 2007, p. 92.

53 Pilkey/Pilkey-Jarvis 2007, p. 109. See for a technical discussion of the model in question, Pilkey and Cooper 2004.

54 Pilkey/Pilkey-Jarvis 2007, p. xii.

55 "The editor of the principle coastal engineering journal of the American Society of Civic Engineers informed a mutual friend that he would never allow a paper by me to be published. And he kept his word.” Pilkey/Pilkey-Jarvis, 2007, p. 136.

56 Pilkey/Pilkey-Jarvis 2007, p. xiii.

57 Koppla/Whitman 2004. The conjunction is not entirely unprecedented and goes back some time (even Nietzsche and certainly Bataille drew inspiration from economic notions). See the 
of science, not to mention the potential scope of computer-generated data on the basis of a given model, the irrelevance of the predictive power of the model for its deployment can seem minor.

Practical questions of a hermeneutic kind are essential to the standard invocation of the working powers of science and technology. And yet if, as in this case, the applied and the pure, the natural and the social sciences go hand in glove with what the idealization of science in our culture. Hence although the authors themselves are scientists-having written their book for the sake of applying that same science to applied engineering to better, more efficient end-results-the critical dissonance that is part of the Pilkeys' arguments tends to alienate some readers. By contrast more readers will find it easier to read an author like Naomi Oreskes, who is more "readable" owing to her politically judicious criticism of the political uses of science (big tobacco being a perfect fall guy, the Army Corps of Engineers, even after Hurricane Katrina, even after a federal judge held the Corps "accountable for the destruction of most of New Orleans,"58 much less so). Hence readers have tended to challenged by Useless Arithmetic and its insistent call for more science when it comes to the deployment of models.

The example of shoreline modelling, beaches and storms and sand, concern engineering, an applied science, yet these considerations bear on sociology and technology and science studies. The Pilkeys do not use the word "hermeneutics," but their description of the dominant paradigm in their field as a "fig leaf" for other interests, masking the subjective concerns haunting practices assumed objective, has limited the reception of their work. ${ }^{59}$ This is regrettable as the mathematician, Ralph Abraham, argues, invoking "the hermeneutical circle that

contributions, particularly that of Philip Mirowski, to Lavoie 1990. For a discussion of Lavoie himself see the introduction to High 2006 which delineates layers of interpretation (more turtles) in addition to the hermeneutic. Cf. here Wayne Froman's chapter in the same volume: Froman 2006, pp. $164 \mathrm{ff}$. and see especially Gary Madison's contribution. In addition to Madison's first two books, see his (1989) and his (1994). See too Mirowski's monograph, now its second edition, Mirowski 2000.

58 Grunwald 2009.

59 Carpenter in his review (2013) points to the general appreciation of computer models and focuses, despite a positive review, on just those instances where models work. A more insightful review pointing to the authors' push for "more adaptive management practices" is on offer in Cockerill 2007. And in a review published in Nature, Roger Pielke, Jr. explicates the cognitive dissonance for scientists committed to precisely the opposite conviction contra the author's central claim regarding "the virtual impossibility of accurate quantitative modelling to predict the outcome of natural processes on the Earth's surface'.” Pielke 2007, p. 35-36. 
drives the advance of science" 60 in the context of the "modeling of complex dynamical systems" and the "misuse of mathematical modeling" in the Pilkeys' instantiations of these cases as (to repeat Abraham's own summary of the modeling strategies already listed above) as

including the collapse of Atlantic cod stocks, prediction of stock prices, body counts during the Vietnam war, the safety of nuclear waste storage at Yucca Mountain in Nevada, the rise of sea levels due to global climate warming, shoreline erosion, toxicity of abandoned openpit mines, and the spread of non-indigenous plants. ${ }^{61}$

The Pilkeys' critical project requires hermeneutics. But if Abraham draws conclusions which may upset some journalistic science writers and delight others (on Global Warming and climate change-we are after all, with a century or two of measurement data not exactly replete with rich sample material one way or the other), Abraham's point is unambiguous, going further than the authors of Useless Arithmetic:

policy makers with their own agendas may fool people (and themselves) into accepting risky policies by misrepresenting simulated data as prediction. This is what the Pilkeys mean by useless arithmetic. But it is worse than useless, it is dangerous. ${ }^{62}$

Pilkey himself invokes an iconic example to illustrate the "measurement of sand transport" (useful, as one might assume, for those involved with shore-erosion management simply in order to know how much sand to order at any given time, just to know what was displaced so to perhaps compensate). But not only are the models not particularly helpful, the tests of the same are inconclusive. Thus:

Sam Smith, an Australian coastal engineer, thought he had a solution in measuring the storm problem. He spread a dump truck load of blue-dyed fluorescent sand along a Gold Coast beach in Australia as a typhoon approached the shore. Smith figured he would be able to find at least a few grains and thus learn the direction in which sand was moved. After the storm, however, not a single blue sand grain was found. ${ }^{63}$

I cite this as it exemplifies a hermeneutic insight into science otherwise advanced by Nietzsche, along with the revelation of the contrary results of the experiment-one part Canute, one part Lewis Carrol and nursery rhymes about

60 Abraham 2009, p. 1.

61 Abraham 2009, p. 2.

62 Abraham 2009, p. 2.

63 Pilkey and Pilkey-Jarvis 2007, p. 123. 
maids sweeping the sea shore. At issue is the ocean itself and the wave, chaos and disorder and regularity. This is the reference to complexity as one finds it in Nietzsche's own high Kantian reference to causality and its noumenal complexity:

Die wahre Welt der Ursachen ist uns verborgen; sie ist unsaglich komplizierter. Der Intellekt und die Sinne sind ein vor allem vereinfachter Apparat. [The true world of causes is concealed from us. The intellect and the senses are above all a simplifying apparatus. $]^{64}$

Nietzsche's point is not directed to the externality of the world and focuses on nothing less than consciousness, the self, the ego as a collimated kind of "end-phenomenon" as he names it, of what we perceive of ourselves in terms of what we call our "feeling willing thinking," the "causes of which are unknown to us" apart from the "succession" of the same "end-phenomena." 65 For Nietzsche there is no kind of fundamental spiritual or intellectual reality at the base of these appearances. Once again "the true world of causes is concealed from us." ${ }^{66}$ It is in that sense that Nietzsche emphasizes "the unspeakable complexity" of that world and it is concomitant with that same complexity that he writes that "the intellect and the senses are above all a simplifying apparatus." 67 The simplifying note he adds is intended as an explication: all one needs for a sense of this is to study the body: physiology as such. Add political and cultural history to that, sociology, politics, what have you, complexities only increase.

The difficulty here (this what Abraham named "dangerous") concerns more than the differences between engineering- and science-based approaches but policy making: nothing other than the politics of environmental science not on the level of legislation and enforcement but politics on the level of science itself as indeed of technology as such. ${ }^{68}$

64 Nietzsche, KSA 11, 34 [46], p. 434. My translation. See too Simon 1989. And on Kant and Nietzsche, including other references to the literature, see Babich 2016a. Günter Abel in his closing chapter to the essays included in his co-edited volume, Nietzsches Wissenschaftsphilosophie refers to Goodman and his "ways of worldmaking" and art to address some of this also invokes Feyerabend. Abel 2011. For me this is at the heart of Alwin Mittasch's approach to Nietzsche, especially the language of a chemistry of sensations and sensibility, including broad parallels with Paneth or Schrödinger.

65 Nietzsche, KSA 11, 34 [46], p. 434. My translation.

66 Nietzsche, KSA 11, 34 [46], p. 434. My translation.

67 Nietzsche, KSA 11, 34 [46], p. 434. My translation.

68 Some scholars do explore this conjunction. See, for example, Sarewitz 1996 as well as Winner 1988. What can pass unread in today's age that endorses a recovery of Simondon and Souriau can be the very classic and otherwise increasingly excluded Ellul 1967. 


\section{Conclusion: Politics and Hermeneutic Philosophy of Science}

Philosophy of science has a political side even if political theorists themselves, subtribe as they are of the discipline of political science, tend to be charry of pointing this out. If Max Weber is an exception as is Bruno Latour, Latour himself is also a model example of the disastrous consequences of hinting that there might be a social element in science-political, sociological, anthropological. ${ }^{69}$ Tarred with consructivism and saddled with the rubric of postmodernism, Latour turned away from his original efforts, decisively as far as I can see, not only for his own work but in social science and technology studies overall, in order to sidestep the negative press associated with what was (then) decried as social construction and its various discontents. ${ }^{70}$

If Alasdair MacIntyre has had ${ }^{71}$ the rare confidence required to point to the influence of the political in what counts and what can be counted as a fact, ${ }^{72}$ the very pointing to the social, let alone the political, not to speak of hermeneutics, has made many philosophers of science uncomfortable, even disquieting thinkers in science studies as in the sociology of science and technology.

Yet in recent years there has been both an efflorescence of hermeneutics and a step away from hermeneutics in the social sciences themselves and in philosophical expressions bearing on the social sciences. ${ }^{73}$ Perhaps this has to do, as the above discussion would suggest, with an aspiration towards objective status on the model of the natural sciences (which as both Kockelmans and Heelan argue in this volume likewise include hermeneutical elements) or perhaps this simply reflects disciplinary shifts at the level of the university, or, in philosophy this may have to do with changes in formation and the near exclusive dominance of analytic conventions. ${ }^{74}$ In any case, hermeneutics remains an indispensable

69 See Latour 1999. See for one, largely conventional reading, Brown 2009.

70 See again, already cited above, the concluding sections of Babich 2017.

71 For a discussion, see Dolling 2002.

72 I refer to Macintyre's discussion of "The Idea of Social Science" in After Virtue. To me it is regrettable that MacIntyre who discusses Winch and Durkheim in addition to Goffman, does not himself draw a connection to hermeneutics. See however Laitinen 2015. And see too, specifically on Gadamer, MacIntyre 2002.

73 For Kockelmans on the social sciences, in addition to his chapter in the current volume, see Kockelmans 1976, 1978 and 1979.

74 See Babich 2012. There is another set of complex questions among the many remaining beyond the scope of this essay which would allow one to determine the consequences of choosing for phenomenology over hermeneutics in a certain tradition at least in sociology, to wit Ferguson 
ingredient in any account, contemporary or historical, of scientific practice and to that same extent indispensable for any philosophy of science that means to proceed along the path of science.

\section{References}

Abel, Günter (2011). “Die Aktualität der Wissenschaftsphilosophie Nietzsches.” In: Helmut Heit, Günter Abel, and Marco Brusotti, (eds.) Nietzsches Wissenschaftsphilosophie. Hintergründe, Wirkungen und Aktualität. Berlin: de Gruyter, pp. 481-530.

Arvan, Marcus (2014) “A Campaign for Better Philosophy Citation Practices?” April 24, 2014. Online: http://philosopherscocoon.typepad.com/blog/2014/04/a-campaign-for-better-phi losophy-citation-practices.html. Last accessed 05.24.2017

Aucoin, Pauline McKenzie (2017) "Toward an Anthropological Understanding of Space and Place." In: Bruce B. Janz (ed.), Place, Space and Hermeneutics, Frankfurt a.M.: Springer, pp. 395- 412.

Babich, Babette (2003) "Paradigms and Thoughtstyles: Incommensurability and its Cold War Discontents from Kuhn's Harvard to Fleck's Unsung Lvov.” Social Epistemology 17: 97-107.

Babich, Babette (2010) "Towards a Critical Philosophy of Science: Continental Beginnings and Bugbears, Whigs and Waterbears." International Journal of the Philosophy of Science 24 (4): $343-391$.

Babich, Babette (2011) Nietzsches Wissenschaftsphilosophie. Oxford: Peter Lang.

Babich, Babette (2012) La fin de la pensée. Paris: L'Harmattan.

Babich, Babette (2014) "Nietzsche's Antichrist: The Birth of Modern Science out of the Spirit of Religion." In: Markus Enders and Holger Zaborowski (eds.), Jahrbuch für Religionsphilosophie. Freiburg i. Br.: Alber, pp. 134-154.

Babich, Babette (2015) “Calling Science Pseudoscience: Fleck's Archaeologies, Latour's Biography, and Demarcation or AIDS Denialism, Homeopathy, and Syphilis." International Studies in the Philosophy of Science. Vol. 29, Nr. 1 (2015): 1-39.

Babich, Babette (2016a) “Nietzsche's Critique: Reading Kant’s Critical Philosophy.” In: Mark Conard (ed.), Nietzsche and the Philosophers. Lanham, MD: Rowman Littlefield, pp. 171-192.

Babich, Babette (2016b) “Getting to Hogwarts: Michael Oakeshott, Ivan Illich, and J.K. Rowling on 'School'." In: David Bakhurst and Paul Fairfield (eds.), Education and Conversation: Exploring Oakeshott's Legacy. London: Bloomsbury, pp. 199-218.

Babich, Babette (2017) "Are They Good? Are They Bad? Double Hermeneutics and Citation in Philosophy, Asphodel and Alan Rickman, Bruno Latour and the 'Science Wars'." In: Paula Angelova, Jaassen Andreev, Emil Lessky (eds.) Das Interpretative Universum. Würzburg: Königshausen \& Neumann, pp. 259-290.

Babich, Babette (2018) “ Les “ pseudosciences “ à l'aune de l'échelle des valeurs de l'université. " Diversité linguistique et culturelle, appropriations, réceptions

2006, and some of the contributions in the present volume bear witness to this influence, as it also grows out of Schütz 1967. 
Francophonies, formations à distance, migrances. Réflexions épistémologiques et interventions. Actes du colloque de Tours (9-10.06.16). Forthcoming.

Bardini, Thierry (2011) Junkware. Minneapolis: University of Minnesota Press.

Bischur, Daniel (2013), "Scientific Practice and the World of Working” in: Michael Staudigl and George Berguno (eds.) Schutzian Phenomenology and Hermeneutic Traditions, Springer: Frankfurt a.M., pp. 126-198.

Carson, Cathryn, Alexei Kojevnikov, and Helmuth Trischler (eds.) (2011) Weimar Culture and Quantum Mechanics: Selected Papers by Paul Forman and Contemporary Perspectives on the Forman Thesis. Hackensack, N.J.: World Scientific Publishing.

Cole, Stephen, Leonard Rubin, Jonathan R. Cole, (1978) Peer Review in the National Science Foundation: Phase One of a Study : Prepared for the Committee on Science and Public Policy of the National Academy of Sciences. Washington, DC: National Academies.

Connor, Steven (2016) "Decomposing the Humanities." New Literary History 47(2 \& 3, Spring \& Summer), pp. $275-288$.

Corneliussen, Steven T. (2017) “Commentators Reexamine Physicist Alan Sokal's Purposeful 1996 Parody Paper: 'Transgressing the Boundaries: Towards a Transformative Hermeneutics of Quantum Gravity' Still Packs a Sly Punch,” Physics Today 26 Jan.

Cutrofello, Andrew (2004) Continental Philosophy: A Contemporary Introduction. London: Routledge.

Dallmayr, Fred. (2013) "The Return of Philosophical Anthropology." In: Ananta Kumar Giri and John Clammer (eds.) Philosophy and Anthropology: Border Crossing and Transformations. London: Anthem Press, pp. 367-378.

Duhem, Pierre (1991 [1916]) German Science. Some Reflections on German Science. German Science and German Virtues, tr. John Lyon. La Salle: Open Court.

Feyerabend, Paul (1985) "Galileo and the Tyranny of Truth." In: G.V. Coyne (ed.) The Galileo Affair: A Meeting of Faith and Science, Proceedings of the Cracow Conference, May 24-27, 1984. Citta del Vaticano: Specola Vaticana, pp. 155-166.

Feyerabend, Paul (1993 [1975]) Against Method. London: Verso.

Finocchiaro, Maurice (2010) Defending Copernicus and Galileo: Critical Reasoning in the Two Affairs. Frankfurt a.M.: Springer.

Fleck, Ludwik (1979) On the Genesis and Development of a Scientific Fact. Chicago: University of Chicago Press.

Fleck, Ludwik (2008) Genèse et développement d'un fait scientifique, tr. Nathalie Jas. Paris: Champs scientifique.

Forman, Paul (1971) "Weimar Culture, Causality, and Quantum Theory, 1918-1927: Adaptation by German Physicists and Mathematicians to a Hostile Intellectual Environment." Historical Studies in the Physical Sciences, 3(1), pp 1-115.

Gardener, Martin (2013) Undiluted Hocus-Pocus: The Autobiography of Martin Gardner. Princeton: Princeton University Press.

Gane, Mike (2006) Auguste Comte. London: Routledge.

Geertz, Clifford (1996) After the Fact: Two Countries, Four Decades, One Anthropologist. Cambridge: Harvard University Press.

Ginev, Dimitri (1998) "Rhetoric and Double Hermeneutics in the Human Sciences." Human Studies 21: 259-271.

Ginev, Dimitri (2006) The Context of Constitution: Beyond the Edge of Epistemological Justification. Frankfurt a.M.: Springer. 
Glendinning, Simon (2006) The Idea of Continental Philosophy. Edinburgh: Edinburgh University Press.

Heelan, Patrick A. (1965) Quantum Mechanics and Objectivity. Nijhoff: The Hague.

Heelan, Patrick A. (1989) "Yes! There is a Hermeneutic Philosophy of Natural Science: Rejoinder to Markus." Science in Context 3: 469-480.

Heelan, Patrick A. (1994) "Galileo, Luther, and the Hermeneutics of Natural Science" in: T. J. Stapleton (ed.) The Question of Hermeneutics, Dordrecht: Kluwer, pp. 363-375.

Heelan, Patrick A. (2016) The Observable. Oxford/Bern: Peter Lang.

Heidegger, Martin (1996) Hölderlin's Hymn "The Ister”, tr. William McNeill and Julia Davis. Bloomington: Indiana University Press.

Horgan, John (1993) "Profile: Paul Karl Feyerabend-The Worst Enemy of Science." Scientific American 268(5): 36-37.

Kämpf, Heike (2013) "The Engagement of Philosophy and Anthropology in the Interpretive Turn and Beyond: Towards an Anthropology of the Contemporary." In: Ananta Kumar Giri and John Clammer (eds.) Philosophy and Anthropology: Border Crossing and Transformations. London: Anthem Press, pp. 89-104.

Kusch, Martin (2005) Psychologism: The Sociology of Philosophical Knowledge. London: Routledge.

Latour, Bruno (1976) The Force of Knowledge: The Scientific Dimension of Society. Cambridge: Cambridge University Press.

Latour, Bruno (1991a) Nous n'avons jamais été modernes. Essai d'anthropologie symétrique. Paris: La Découverte.

Latour, Bruno (1991b) We Have Never Been Modern. New York: Harvester Wheatsheaf.

Latour, Bruno (1999) Politiques de la nature. Comment faire entrer les sciences en démocratie. Paris: La Découverte.

Latour, Bruno (2001) Das Parlament der Dinge. Frankfurt a.M.: Suhrkamp.

Latour, Bruno (2012) "Biography of an Investigation: On a Book about Modes of Existence. Draft of an Article for a Dossier on AIME," tr. Cathy Porter. Archives de philosophie 75 (4): $1-20$.

Latour, Bruno (2013) An Inquiry Into Modes of Existence: Anthropology of the Moderns. Harvard: Harvard University Press.

Latour, Bruno and Woolgar, Steve (1986 [1979]) Laboratory Life: The Construction of Scientific Facts. London: Sage.

Lau, Joerg (2002) "Bescheidwisser in die Politik." Die Zeit, March 7, 2002.

Leydesdorff, Loet (2006) The Knowledge-Based Economy: Modeled, Measured, Simulated. Boca Raton: Universal-Publishers.

Lynch, William (1993) “What Does the Double Hermeneutic Explain/Justify?” Social Epistemology 7(2): $193-204$.

Márkus, György (1987) "Why is there no Hemeneutics of Natural Sciences. Some Preliminary Theses." Science in Context 1 (1): 5-51.

Maranhāo, Tullio and Bernhard Streck (eds.) (2003) Translation and Ethnography: The Anthropological Challenge of Intercultural Understanding (Tucson: University of Arizona Press, 2003

McCumber, John (1996) Time in the Ditch: American Philosophy and the McCarthy Era. Evanston: Northwestern University Press. 
Nietzsche, Friedrich (1980) Kritische Studienausgabe, (eds.) Giorgio Colli and Mazzino Montinari. Berlin: de Gruyter.

Pelchat, Yolande (2003) L'obsession de la différence: récit d'une biotechnologie. Laval: Presses Université Laval.

Preston, John, Munévar, Gonzalo and Lamb, David (eds.) (2000) The Worst Enemy of Science? Essays in Memory of Paul Feyerabend. Oxford: Oxford University Press.

Rabinow, Paul (2011) The Accompaniment: Assembling the Contemporary. Chicago: University of Chicago Press.

Ringer, Fritz (1969) The Decline of the German Mandarins: The German Academic Community, 1890-1933. Cambridge: Harvard University Press.

Ruark, Jennifer 2017, "Anatomy of a Hoax: Bait and Switch. How the physicist Alan Sokal hoodwinked a group of humanists and why, 20 years later, it still matters. An oral history" Chronical of Higher Education, January 01.

Schmidgen, Henning (2014) Bruno Latour in Pieces: An Intellectual Biography. New York: Fordham University Press.

Schürmann, Reiner (1985) "De la philosophie aux États-Unis” Le temps de la réflexion 6: $303-321$.

Schürmann, Reiner (1994) "Concerning Philosophy in the United States" Social Research, 61 (l, Spring): 89-113.

Shapin, Steven (1992) "Discipline and Bounding: The History and Sociology of Science as Seen through the Externalism-Internalism Debate" History of Science 30: 333-369.

Simon, Joseph (1989) Philosophie des Zeichens. Berlin/New York: De Gruyter.

Smith, Richard (2006) "Peer Review: A Flawed Process at the Heart of Science and Journals," J R Soc Med., 99(4) Apr.: 178-182.

Sokal, Alan (1997a) "Pourquoi j’ai écrit ma parodie." Le Monde, January 31.

Sokal, Alan (1997b) "Nos philosophes sont-ils des imposteurs?" Le Nouvel Observateur 1716, pp. $116-118$.

Sormani, Philippe (2016) Respecifying Lab Ethnography: An Ethnomethodological Study of Experimental Physics. London: Routledge.

Souriau, Étienne (2009) Les différents modes d'existence. Suivi de Du mode d'existence de l'oeuvre à faire avec une présentation par Isabelle Stengers et Bruno Latour. Paris: Presses Universitaires de France.

Stengers, Isabelle (1977) Cosmopolitiques. Vol. 1: La guerre des sciences. Paris/Le Plessis-Robinson: La Découverte.

Warman, Matt (2011) “Stephen Hawking Tells Google 'Philosophy is Dead'." Telegraph, 17 May. 